\title{
Dasatinib impairs long-term expansion of leukemic progenitors in a subset of acute myeloid leukemia cases
}

\author{
Lina Han • Jan Jacob Schuringa • André Mulder • \\ Edo Vellenga
}

Received: 19 January 2010 / Accepted: 17 March 2010 / Published online: 13 April 2010

(C) The Author(s) 2010. This article is published with open access at Springerlink.com

\begin{abstract}
A number of signaling pathways might be frequently disrupted in acute myeloid leukemia (AML). We questioned whether the dual SRC/ABL kinase inhibitor dasatinib can affect AML cells and whether differences can be observed with normal $\mathrm{CD} 34^{+}$cells. First, we demonstrated that normal cord blood (CB) $\mathrm{CD} 34^{+}$cells were unaffected by dasatinib at a low concentration $(0.5 \mathrm{nM})$ in the long-term culture on MS5 stromal cells. No changes were observed in proliferation, differentiation, and colony formation. In a subset of AML cases (3/15), a distinct reduction in cell proliferation was observed, ranging from $48 \%$ to $91 \%$ inhibition at $0.5 \mathrm{nM}$ of dasatinib, in particular, those characterized by BCR-ABL or KIT mutations. Moreover, the inhibitory effects of dasatinib were cytokine specific. Stem cell factor-mediated proliferation was significantly impaired, associated with a reduced phosphorylation of ERK1/2 and STAT5, whereas no effect was observed on interleukin-3 and thrombopoietin-mediated signaling despite
\end{abstract}

Electronic supplementary material The online version of this article (doi:10.1007/s00277-010-0948-7) contains supplementary material, which is available to authorized users.

L. Han · J. J. Schuringa $\cdot$ E. Vellenga $(\bowtie)$

Department of Hematology, University of Groningen and University Medical Center Groningen,

P.O. Box 30001, 9700 RB Groningen, the Netherlands

e-mail: e.vellenga@int.umcg.nl

L. Han

Department of Hematology,

The First Clinical College of Harbin Medical University,

Harbin, China

\section{A. Mulder}

Department of Clinical Chemistry, University of Groningen and University Medical Center Groningen,

Groningen, the Netherlands
SRC activation. In conclusion, this study demonstrates that dasatinib is a potential inhibitor in a subgroup of AML, especially those that express BCR-ABL or KIT mutations.

Keywords Acute myeloid leukemia · Dasatinib .

SRC family kinases $\cdot$ KIT mutation

\section{Introduction}

Acute myeloid leukemia (AML) is a clonal hematopoietic disorder with an early block in the differentiation program. The malignant disorder is organized in hierarchy whereby a limited number of cells, which are considered leukemic initiating cells (LICs), have the property to maintain the leukemic phenotype and are enriched in the $\mathrm{CD} 34^{+}$cell fraction $[1,2]$. The malignant transformation in AML has been proposed as the consequence of collaboration between several mutations, including both mutations in transcription factors resulting in impaired differentiation and constitutively activated receptor tyrosine kinases (RTKs), such as FLT3 and KIT, conferring proliferative and survival advantages to hematopoietic cells [3].

Dasatinib has been designed as a dual ABL/SRC family kinase (SFK) inhibitor [4]. It is effective in imatinibresistant chronic myeloid leukemia (CML) by binding both the active and inactive form of BCR-ABL, as well as the SFKs, and subsequently affects also the important downstream targets including STAT5 and ERK1/2 [5-7]. Dasatinib is also known as kinase inhibitor of KIT and platelet-derived growth factor receptor, as well as ephrin A receptor kinases [4, 8]. Nonreceptor protein tyrosine kinases (TKs) including SFKs interact with and participate in signaling from RTKs [9]. It has been demonstrated that Lyn, a member of SFKs, is an important component of the 
signal transduction pathway as an intermediate signal component linking FLT3/ITD to STAT5 [10]. These SFKs are frequently constitutively expressed in AML, especially Lyn, Hck, and Fgr [11]. KIT expression was detected in approximately $70 \%$ of de novo AMLs and $95 \%$ of relapsed AMLs [12]. The increased KIT intensity was correlated with decreased overall survival in AML patients [13]. And KIT mutations have been preferentially associated with core-binding factor (CBF) AML with either an inv(16) or a $\mathrm{t}(8 ; 21)$ karyotype [14]. In vitro study has shown that dasatinib at low dose can inhibit the proliferation of AML Kasumi-1 cell line, which has a gain-of-function KIT mutation [15]. A recent case report showed that combined treatment with chemotherapy and dasatinib could achieve long-term hematologic and molecular remission in a patient with systemic mastocytosis and AML with mutant KITD816V expression [16]. So far, it is unresolved whether patients' AML cells are affected by dasatinib because, in AML cells, a number of collaborative signaling pathways might be disrupted. Here we performed long-term cultures with AML CD34 ${ }^{+}$cells, as well as normal cord blood (CB) $\mathrm{CD} 34^{+}$cells on MS5 murine stromal cells in the absence or presence of dasatinib, to study the long-term expansion, self-renewal, and hematopoietic differentiation.

\section{Materials and methods}

\section{Reagents and antibodies}

Dasatinib (BMS-354825) was provided by Bristol-Myers Squibb Company (Princeton, NJ, USA) and prepared as a $10 \mathrm{mM}$ stock solution in dimethylsulfoxide (DMSO), stored in aliquots at $-20^{\circ} \mathrm{C}$, and diluted in DMSO before treatment on the cells. Purified mouse anti-human STAT5 (pY694), CD11b-PE, CD14-FITC, and CD15-APC were purchased from BD Biosciences (Breda, the Netherlands). Phospho-SRC family (Tyr416) antibody, phospho-ERK1/2 (Thr202/Tyr204) antibody, and phospho-p70 S6 kinase (Thr389) antibody were purchased from Cell Signaling (Leiden, the Netherlands). ERK1 antibody was obtained from Santa Cruz Biotechnology (Santa Cruz, CA, USA).

Isolation of normal and leukemic $\mathrm{CD} 34^{+}$cells

Normal CD $34^{+}$cells were derived from neonatal CB from healthy full-term pregnancies from the obstetrics departments of the Martini Hospital and University Medical Center in Groningen, the Netherlands, after informed consent. After Ficoll separation of mononuclear cells, $\mathrm{CD}_{3} 4^{+}$cells were enriched by magnetically activated cell-sorting CD34 progenitor kit (Miltenyi Biotec, Utrecht, the Netherlands). Acute myeloid leukemia blasts from peripheral blood cells or bone marrow cells from untreated patients with AML were studied after informed consent. Acute myeloid leukemia mononuclear cells were isolated by density gradient centrifugation, and $\mathrm{CD} 34^{+}$cells were selected by MoFLo sorting (DakoCytomation, Carpinteria, CA, USA).

Liquid culture conditions of cell lines and primary cells

K562 cell line was cultured in RPMI 1640 medium (Biowhittaker, Verviers, Belgium) supplemented with Lglutamate, $10 \%$ fetal calf serum (FCS; Sigma, Zwijndrecht, the Netherlands), and $1 \%$ penicillin/streptomycin $(\mathrm{P} / \mathrm{S})$. Mo7e cell line was routinely propagated in RPMI 1640 with $5 \% \mathrm{FCS}, 1 \% \mathrm{P} / \mathrm{S}$, and $10 \mathrm{ng} / \mathrm{ml}$ interleukin-3 (IL-3; Gist-Brocades, Delft, the Netherlands). Before preparing cell lysates, Mo7e cells were deprived of cytokine overnight in RPMI with $0.5 \%$ FCS and subsequently stimulated with $20 \mathrm{ng} / \mathrm{ml}$ stem cell factor (SCF; Immunex Corporation, Seattle, WA), IL-3, or thrombopoietin (TPO; Kirin, Tokyo, Japan) for 15 min, separately. Dasatinib was added $2 \mathrm{~h}$ before cytokine stimulation. SKNO-1 cell line (kindly provided by Prof. Dr. M. Lübbert) was routinely propagated in RPMI 1640 with $10 \%$ FCS, $1 \% \mathrm{P} / \mathrm{S}$, and with $10 \mathrm{ng} / \mathrm{ml}$ granulocyte macrophage colony-stimulating factor (GM-CSF; Genetics Institute, Cambridge). Thirty thousand $\mathrm{CB} \mathrm{CD} 34^{+}$cells were cultured in Iscove's modified Dulbecco's (IMD) medium (PAA Laboratories, Pasching, Austria) supplemented with $10 \%$ FCS, $1 \%$ glutamine, and $1 \% \mathrm{P} / \mathrm{S}$, supplemented with the following cytokines: SCF $(20 \mathrm{ng} / \mathrm{ml}), \mathrm{IL}-3(20 \mathrm{ng} / \mathrm{ml})$, or in combination (SCF with IL-3 at $20 \mathrm{ng} / \mathrm{ml})$, or TPO (20 ng/ml) combined with IL-3 $(5 \mathrm{ng} / \mathrm{ml})$. Cultures were demi-depopulated at days 7 and 14 for analysis.

Long-term cultures on MS5 stromal cells

The 40,000 AML CD34 ${ }^{+}$cells were plated in 12-well plates precoated with MS5 stromal cells. Cells were expanded in LTC medium ( $\alpha$-MEM supplemented with heat-inactivated $12.5 \%$ FCS, heat-inactivated $12.5 \%$ horse serum, $\mathrm{P} / \mathrm{S}$, $2 \mathrm{mM}$ glutamine, $57.2 \mu \mathrm{M} \beta$-mercaptoethanol and $1 \mu \mathrm{M}$ hydrocortisone) (all from Sigma) supplemented with $20 \mathrm{ng} / \mathrm{ml} \mathrm{IL}-3$, granulocyte colony-stimulating factor (GCSF; Rhone-Poulenc Rorer, Amstelveen, The Netherlands), and TPO as described previously [17, 18]. Cultures were kept at $37^{\circ} \mathrm{C}$ and $5 \% \mathrm{CO}_{2}$ and demi-depopulated weekly for analysis. In cocultures that generated leukemic cobblestone areas (L-CAs), leukemic cells could be harvested from these cocultures after 3 to 5 weeks to initiate secondary cocultures on new MS5 stroma, a feature of self-renewing cells that we do not observe with normal CB. Thirty thousand $\mathrm{CB} \mathrm{CD}_{3} 4^{+}$cells were plated in $\mathrm{T}-25$ flasks 
precoated with MS5 stromal cells. Cells were expanded in LTC medium and demi-depopulated weekly for analysis. One hundred thousand SKNO-1 cells were plated in MS5 stromal cells precoated 12-well plates, expanding in RPMI with $10 \% \mathrm{FCS}$ and $1 \% \mathrm{P} / \mathrm{S}$, with or without $10 \mathrm{ng} / \mathrm{ml} \mathrm{GM-}$ CSF. Demi-depopulation was performed.

\section{KIT and FLT3 mutation analysis}

Detection of the KIT-D816V mutation was performed with real-time polymerase chain reaction $(\mathrm{PCR})$ using primers 5'-TTGTGATTTTGGTCTAGCCAGACT-3' and 5'GTGCCATCCACTTCACAGGTAG-3' according to the previous study [19]. Mutational analysis of ITD within the JM domain of the FLT3 gene was performed with reverse transcriptase PCR using primers 5'-CAATTTAGGTAT GAAAGCC-3' and 5'-CAAACTCTAAATTTTCTCT-3', as previously described [20].

Colony-forming cell assay

Colony-forming cell (CFC) assay was performed as previously described [21]. Briefly, CFC assays were performed in $1.2 \%$ methylcellulose containing $30 \%$ FCS, $57.2 \mu \mathrm{M} \beta$-mercaptoethanol, and $2 \mathrm{mM}$ glutamine (StemCell Technologies, Meylan, France), supplemented with $20 \mathrm{ng} / \mathrm{ml} \mathrm{IL-3,} \mathrm{IL-6,} \mathrm{G-CSF,} \mathrm{SCF,} \mathrm{and} 1 \mathrm{U} / \mathrm{ml}$ erythropoietin (Epo, Cilag; Eprex, Brussels, Belgium). One thousand fresh CB CD34 $4^{+}$cells or $10^{4}$ expanded cells from MS5 coculture were plated in 1-ml CFC mixes per 35-mm dish in duplicate. The colonies were scored 2 weeks later.

Fluorescence-activated cell sorter analysis

Cells were incubated with antibodies at $4{ }^{\circ} \mathrm{C}$ for $30 \mathrm{~min}$ before the analysis on a FACSCalibur (Becton Dickinson). Data were analyzed using WinList 6.0 (Topsham, ME, USA).

\section{Cell lysis and Western blotting}

Whole cell lysates were prepared in boiling sample buffer (containing $2 \%$ sodium dodecyl sulfate [SDS], 10\% glycerol, 2\% $\beta$-mercaptoethanol, $60 \mathrm{mM}$ Tris-HCl, $\mathrm{pH}$ 6.8 , and bromophenol blue). Protein aliquots were equally resolved by $10 \%$ SDS polyacrylamide gel electrophoresis and transferred to nitrocellulose membranes (Millipore, Etten Leur, the Netherlands) using a semidry electroblotter from Biorad (Veenendaal, the Netherlands). The membranes were blocked in phosphate-buffered saline Tween 20 containing 5\% nonfat milk before incubation with primary antibodies. Detection was performed with horseradish peroxidase-conjugated secondary antibody (DakoCytoma- tion, Glostrup, Denmark) and enhanced chemiluminescence (ECL) reagent (Roche Diagnostics, Basel, Switzerland).

Analysis of cell proliferation

K562 and Mo7e cells were suspended to a final concentration of $1 \times 10^{5}$ cells $/ \mathrm{ml}$ in fresh growth mediums, plated in 12-well plate, and incubated with designated concentrations of dasatinib for $72 \mathrm{~h}$. Growth of Mo7e cells was driven by $20 \mathrm{ng} / \mathrm{ml} \mathrm{SCF}$, IL-3, or TPO. Cells were counted with Coulter electronics (Mijdrecht, the Netherlands) after 24, 48 , and $72 \mathrm{~h}$.

Analysis of cell cycle status

K562 cells were harvested after treatment with dasatinib for $24 \mathrm{~h}$ and stained with hypotonic DNA buffer containing sodium citrate $(1 \mathrm{~g} / \mathrm{l}$; Merck, Schiphol-Rijk, the Netherlands), ribonuclease A $(100 \mathrm{mg} / \mathrm{ml})$, propidium iodide (PI; $1 \mathrm{mg} / \mathrm{ml}$ ), and Triton X-100 (1:10 diluted) (Sigma). Samples were analyzed on a FACSCalibur, and data were analyzed with ModFit LT 3.1 (Topsham).

Analysis of apoptosis

K562 cells were incubated with dasatinib for $48 \mathrm{~h}$, and apoptosis was analyzed using an Annexin V staining kit (IQ Products, Groningen, the Netherlands) according to the manufacturer's recommendations. Briefly, cells were harvested, resuspended in $100-\mu 1$ calcium buffer containing $5-\mu \mathrm{l}$ annexin $\mathrm{V}$, and incubated for $20 \mathrm{~min}$ at $4^{\circ} \mathrm{C}$ in the dark. Cells were washed with calcium buffer and subsequently incubated in 300- $\mu$ l calcium buffer containing $2.5 \mu \mathrm{l}$ of PI for $10 \mathrm{~min}$. Analysis was performed on a FACSCalibur with WinList 6.0 Analysis software.

\section{Statistical analysis}

The significance levels were determined by Student $t$ test between experimental groups. Data were reported as mean \pm standard error (SE) of the mean. A two-sided $p$ value $<0.05$ was considered statistically significant.

\section{Results}

Dasatinib impairs proliferation and colony formation, but not differentiation of normal $\mathrm{CB} \mathrm{CD} 34^{+}$cells

The efficacy of dasatinib at low nanomolar concentrations has been demonstrated in the BCR-ABL-positive K562 cell line, as well as in primary $\mathrm{CML} \mathrm{CD} 34^{+}$cells [22-25]. We first verified the effects of dasatinib in K562 cells, for 
defining the optimal dose-response. As depicted in Suppl Fig. a, dasatinib at a concentration of $0.5 \mathrm{nM}$ was already effective in blocking the proliferation of K562 cells, with an optimal inhibitory effect between 2 and $10 \mathrm{nM}$. These inhibitory effects on cell proliferation were associated with a reduced phosphorylation of SRC, ERK1/2, and STAT5 (Suppl Fig. b). Inhibition of these pathways resulted in a cell cycle arrest with an enhanced percentage of cells in the G0/G1 phase with a concomitant decline in cells in S phase $(p<0.05)$ (Suppl Fig. c). Moreover, the changes were associated with an increased number of cells in apoptosis $(p<0.05)$ (Suppl Fig. d).

In contrast to $\mathrm{BCR}-\mathrm{ABL}$, which is specifically expressed in CML, in a subset of acute lymphoblastic leukemia and rarely in AML, the expression of SRC is ubiquitous throughout the normal hematopoietic system, and its activation has been associated with multiple signaling pathways $[26,27]$. In order to study the effects of dasatinib treatment on normal stem/progenitor cells, CB $\mathrm{CD} 34^{+}$cells were expanded on MS5 stromal cells in the absence or presence of dasatinib. Cultures were demidepopulated weekly for cell counting, CFC assays, and fluorescence-activated cell sorter (FACS) analysis on suspension cells. Dasatinib treatment resulted in a dosedependent growth disadvantage of normal $\mathrm{CD} 34^{+}$progenitor cells (Fig. 1a). The growth was only significantly reduced at a higher concentration $(5 \mathrm{nM})$ of dasatinib, with $77.8 \pm 13.1 \%$ of control $(p=0.04)$ at week $2,61.0 \pm 16.5 \%$ of control $(p=0.02)$ at week 3 , and $54.0 \pm 6.3 \%$ of control $(p=$ 0.006 ) at week 4 (Fig. 1b). The treatment with dasatinib $(5 \mathrm{nM})$ resulted in a reduction in total progenitor (CFC) output after 3 weeks of culture $(62.2 \pm 10.3 \%$ of control, $p=$ 0.01) (Fig. 1c). However, the colonies generated per $10^{5}$ suspension cells were not affected by dasatinib treatment (Fig. 1d). To study whether similar results could be obtained in short-term CFC assays, we cultured $10^{4}$ $\mathrm{CD}_{4} 4^{+}$cells in methylcellulose culture assay with and without dasatinib. The results demonstrated no significant suppressive effect of dasatinib on colony formation (Fig. 1e). Finally, FACS analysis of the suspension cells at weeks 2 and 4 showed no changes in the myeloid differentiation markers CD11b, CD14, and CD15, demonstrating the reduced proliferation was not associated with an impaired differentiation (Fig. 1f).

Dasatinib impairs expansion of AML CD $34^{+}$cells in long-term culture only in a subset of cases

It has been shown previously that the propagation of AML cells partially depends on constitutively activation of receptor kinases including FLT3 and KIT, and the autocrine and paracrine production of growth factors that make use of nonreceptor protein TKs [28]. Therefore, AML cells $(n=19)$ were studied in long-term stromal culture assays by using exclusively the sorted $\mathrm{CD} 34^{+}$cell fraction that is enriched for leukemic stem cells, as has been described [17, 18]. The clinical characteristics of the studied patients, including FAB classification, cytogenetics, and defined mutations, are summarized in Table 1. In 79\% (15/19) of the tested AML cases, long-term expanding cocultures could be generated (Fig. 2a, b). Variability in responsiveness of the different AMLs for dasatinib was observed. In $20 \%$ of the cases $(3 / 15)$, a distinct decrease in long-term cell expansion of AML $\mathrm{CD} 34^{+}$cells was already observed at a dose of $0.5 \mathrm{nM}$ dasatinib, ranging from $48 \%$ to $91 \%$ inhibition as compared to the untreated group. This concentration of dasatinib showed less than $15 \%$ growth inhibition in normal $\mathrm{CD} 34^{+}$cells on stroma (Fig. 1a, b). The growth curves of the three AML cases are shown in Fig. 2c-e. To demonstrate whether dasatinib also inhibited the self-renewal potential of the AML CD $34^{+}$cells, we performed replating experiments by harvesting the cells from L-CAs after 3 to 5 weeks of coculture. These cells were subsequently studied for their capacity to initiate second (and third) cocultures on new MS5 stroma (Fig. 2c). The results demonstrated that AML leukemic cells still expanded on new MS5 stroma, and that the inhibitory effect of dasatinib was less pronounced after replating. The AML cells that responded to dasatinib were characterized by chromosomal translocations or mutations in BCR-ABL $(n=1)$, KIT $(n=1)$, or undetermined $(n=1)$ mutations. In six FLT3-ITD-positive AMLs, no suppressive effects of dasatinib on cell expansion were noticed. Moreover, it appeared that the responsiveness to dasatinib was independent of the level of SRC mRNA expression (data not shown). A remarkable finding was the fact that in the additional AMLs (11/15), a stimulatory effect on cell proliferation was observed at low-dose $(0.5 \mathrm{nM})$ dasatinib when the AML CD34 ${ }^{+}$cells were cultured in long-term stromal assay (Fig. 2a). An increase of 474\% (range, 17$2417 \%$ ) was observed in time. This effect of dasatinib was noticed after a period of 2 to 3 weeks of culture. At a higher concentration $(5 \mathrm{nM})$, this stimulatory effect disappeared in most of the cases (Fig. 2b). Taken together, dasatinib shows pronounced inhibitory effects on proliferation in a subset of AML $\mathrm{CD} 34^{+}$progenitor cells, whereas in the additional cases, a stimulatory effect might be shown at low dose.

Dasatinib selectively impairs SCF-induced and mutant KIT-driven signal transduction and proliferation

In view of the observed suppressive effects of dasatinib in a mutant KIT AML, we further defined the role of dasatinib on KIT receptor signaling by using cell line models with either wild type (wt) (Mo7e cell line) or mutant KIT receptor (SKNO-1 cell line), as well as in primary $\mathrm{CB}$ 
a)

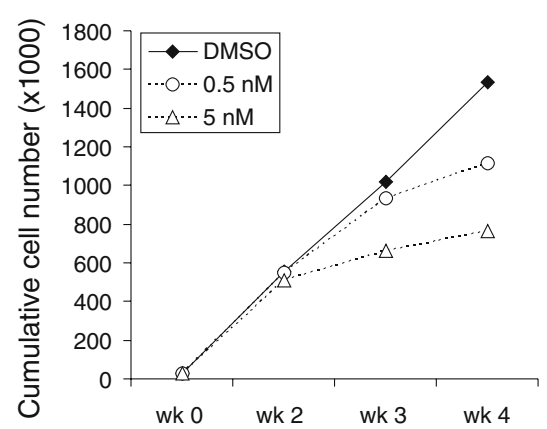

c)

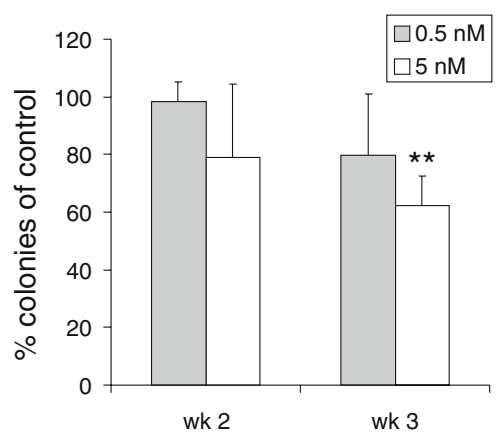

b)

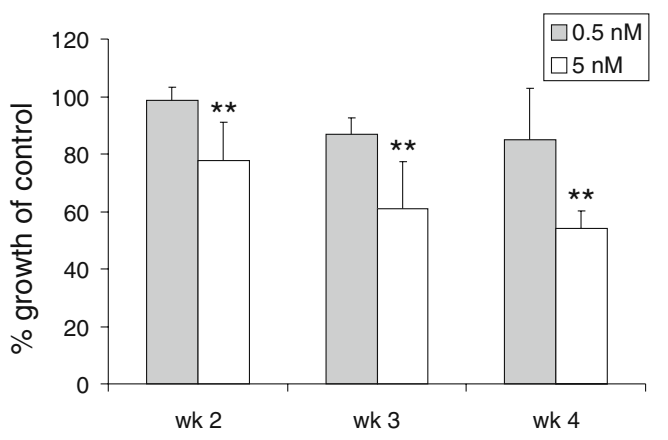

d)

CFCs $/ 10,000$ cells

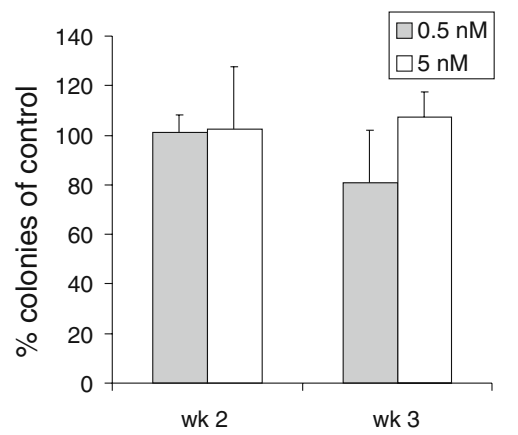

e)

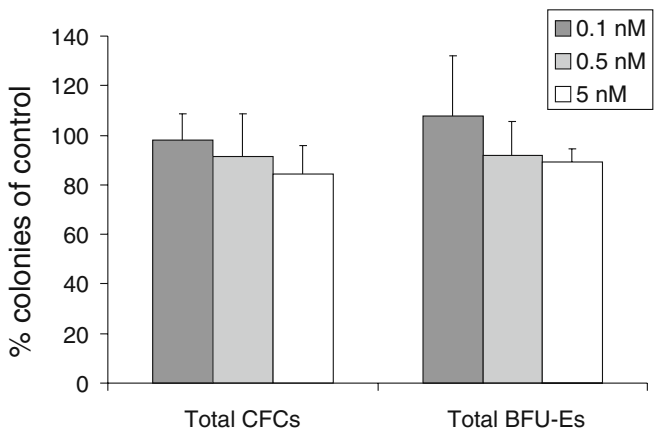

f)
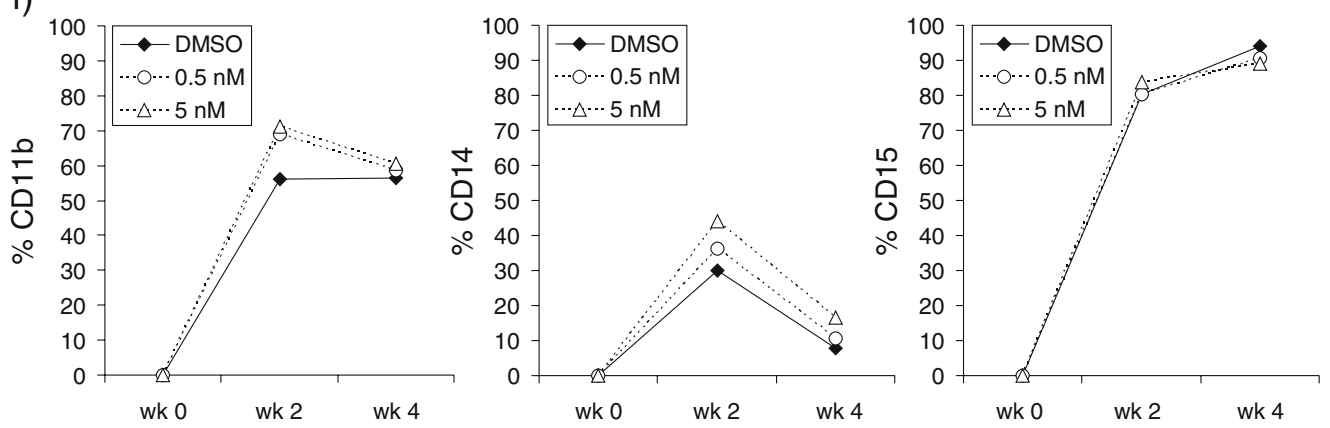

Fig. 1 Dasatinib impairs proliferation, but not colony formation and differentiation of human $\mathrm{CB} \mathrm{CD} 34^{+}$progenitor cells. Cord blood CD $34^{+}$cells $\left(3 \times 10^{4}\right)$ were plated in T25 flask precoated with MS5 stromal cells. Cells were expanded in LTC medium with dasatinib added weekly as indicated. Cultures were demi-depopulated weekly for counting and CFC assay. a Representative figure of weekly cumulative cell counts is shown. b Percentages of cell growth as compared to the control group (\% growth of control) on stroma by adding dasatinib are shown as mean value from three independent coculture experiments. c The total number of CFCs generated per T25 flask was calculated by the number of $\mathrm{CFCs} / 10^{4}$ plated cells multiplied by the cell counts weekly. Percentages of colonies as compared to the control group ( $\%$ colonies of control) after dasatinib

treatment are shown. Data were from three independent coculture experiments. d Cells $\left(10^{4}\right)$ in suspension were plated at weeks 2 and 3 for CFC assay. Percentages of colonies as compared to the control group (\% colonies of control) after dasatinib treatment are shown. e One thousand freshly isolated $\mathrm{CB} \mathrm{CD} 34^{+}$cells were analyzed for $\mathrm{CFC}$ assay. Percentages of colonies as compared to the control group (\% colonies of control) after dasatinib treatment are shown. Data were from three independent experiments. $\mathbf{f}$ The myeloid differentiation of cells in suspension from the coculture system was monitored by FACS with antibodies against CD11b, CD14, and CD15 at weeks 2 and 4. Representative figures out of three independent experiments are shown. Columns, means of three independent experiments; bars, SE $(* * p<0.05)$

$\mathrm{CD} 34^{+}$cells. We cultured the human myeloid leukemia cell line Mo7e with SCF, IL-3, and TPO, and effects on proliferation and downstream signaling pathways were studied. The results showed that Mo7e cells cultured with SCF demonstrated a significant decline in cell proliferation at $5 \mathrm{nM}$, after culturing for $72 \mathrm{~h}(44 \pm 9 \%$ inhibition, $p<$
0.05). No inhibitory effect of dasatinib was shown if the Mo7e cells were cultured with IL-3 or TPO or combinations (Fig. 3a). In addition, we studied the downstream targets that were inhibited by dasatinib and compared the results with K562 cell line. As depicted in Fig. 3b, constitutive phosphorylation of SRC and STAT5, but not 
Table 1 Summary of patient's clinical parameters
AML cells derived from bone marrow (BM) or peripheral blood (PB); Percentage of $\mathrm{CD}^{+} 4^{+}\left(\% \mathrm{CD} 4^{+}\right)$in the total AML mononuclear cell fraction; AML CD34 ${ }^{+}$cells cultured in long-term culture assay demonstrated an expansion $(\mathrm{y} / \mathrm{n}) ; \mathrm{FAB}$, French-American-British classifications; FLT3-ITD (internal tandem duplication) was present $(+)$ or absent (-) in the AML cells; ND, not determined; $\mathrm{N}$, normal

\begin{tabular}{|c|c|c|c|c|c|c|c|}
\hline Patient ID & FAB & $\% \mathrm{CD}_{3} 4^{+}$ & $\mathrm{BM} / \mathrm{PB}$ & Expansion & Karyotype & FLT3-ITD & KIT mutation \\
\hline 1 & M7 & 43 & PB & Yes & $-7 ;+21$ & - & - \\
\hline 2 & M2 & 26 & $\mathrm{~PB}$ & Yes & BCR-ABL, inv (16) & - & ND \\
\hline 3 & M2 & 42 & $\mathrm{BM}$ & Yes & $\mathrm{t}(8 ; 21)$ & - & + \\
\hline 4 & M2 & 52 & PB & Yes & $\mathrm{N}$ & + & ND \\
\hline 5 & M0 & 22 & PB & Yes & $\mathrm{N}$ & + & - \\
\hline 6 & M5 & 88 & PB & Yes & $\mathrm{N}$ & - & ND \\
\hline 7 & M1 & 70 & $\mathrm{BM}$ & Yes & $+3 \mathrm{q} ;-7 ;-10$ & - & - \\
\hline 8 & M0 & 70 & $\mathrm{BM}$ & Yes & $5 q-;+6$ & - & ND \\
\hline 9 & M1 & 19 & $\mathrm{~PB}$ & Yes & $\mathrm{N}$ & + & - \\
\hline 10 & M1 & 19 & PB & Yes & $\mathrm{N}$ & ND & ND \\
\hline 11 & M1 & 35 & $\mathrm{BM}$ & Yes & $\mathrm{N}$ & + & - \\
\hline 12 & M5 & 14 & PB & Yes & $\mathrm{t}(11 ; 20)$ & + & - \\
\hline 13 & M1 & 57 & PB & Yes & $\mathrm{N}$ & - & - \\
\hline 14 & M5 & 10 & $\mathrm{BM}$ & Yes & $\mathrm{ND}$ & - & ND \\
\hline 15 & M5 & 0.5 & PB & Yes & $\mathrm{N}$ & + & ND \\
\hline 16 & M1 & 63 & $\mathrm{~PB}$ & No & $3 p+;-7 ;+8$ & - & - \\
\hline 17 & M1 & 29 & PB & No & del (9) & + & - \\
\hline 18 & M4 & 17 & PB & No & inv (16) & - & + \\
\hline 19 & M5 & 13 & $\mathrm{BM}$ & No & $\mathrm{N}$ & + & ND \\
\hline
\end{tabular}

ERK1/2 and p70S6k, was identified in Mo7e cells. A significant reduction in p-ERK1/2, p-STAT5, and p-p70S6k was shown in SCF-stimulated cells pretreated with dasatinib for $2 \mathrm{~h}$. Moreover, the inhibitory effects were observed at a concentration more than $2 \mathrm{nM}$, whereas the inhibitory effects on BCR-ABL-mediated signaling was already shown at a concentration less than $0.5 \mathrm{nM}$ (Suppl Fig. b). In contrast, no effects were observed on the IL-3 and TPO-mediated phosphorylation. A remarkable finding was that none of the cytokines were strong stimulators for SRC phosphorylation on top of the constitutive levels. Moreover, this SRC activity was not inhibited by dasatinib (Fig. 3b). Taken together, the inhibitory effects on SCF-induced proliferation and signal transduction pathways indicate dasatinib is a stronger KIT kinase inhibitor, rather than an SRC inhibitor.

KIT is expressed in normal stem and progenitor cells, regulating quiescence, self-renewal, and proliferation of stem cells $[29,30]$. Therefore, $\mathrm{CB} \mathrm{CD} 34^{+}$cells were cultured with SCF, IL-3, and TPO to observe whether dasatinib had inhibitory effects on SCF-induced proliferation in normal progenitor cells. Representative growth curves are shown in Fig. 3c, and mean values of growth inhibition are shown in Fig. $3 \mathrm{~d}$. The results showed that $\mathrm{CB}$ CD $34^{+}$cells cultured with SCF demonstrated a significant decline in cell proliferation at $5 \mathrm{nM}(7.8 \pm 0.2 \%$ of control, $p<0.001)$, which was also noticed if SCF was combined with IL-3 $(15.6 \pm 2.8 \%$ of control, $p=0.02)$. No inhibitory effect of dasatinib was shown if the CD $34^{+}$cells were cultured with IL-3, TPO, or combinations. However, IL-3 alleviated the SCF effect (Fig. 3d).
To further evaluate these findings in the malignant counterpart, we used the GM-CSF dependent SKNO-1 cell line, which was characterized by a homozygous N822K KIT mutation [31, 32]. The SKNO-1 cells were studied with and without dasatinib treatment in long-term MS5 stromal culture assay in the presence or absence of GMCSF. SKNO-1 cells showed 17-fold expansion compared to the control cultures without GM-CSF (Fig. 3e). In the presence of GM-CSF, $43 \pm 9 \%$ growth inhibition was achieved at $1 \mathrm{nM}$ of dasatinib $(p>0.05)$, which was further enhanced at $10 \mathrm{nM}(66 \pm 13 \%$ growth inhibition, $p<0.05)$. The inhibitory effects of dasatinib were more pronounced in the absence of GM-CSF (data not shown). Subsequently replating experiments were performed with SKNO-1 cells cultured with

Fig. 2 Dasatinib impairs expansion of a subset of AML CD34 ${ }^{+}$cells in long-term cultures. Acute myeloid leukemia CD $34^{+}$cells $\left(4 \times 10^{4}\right)$ were sorted and plated in 12-well plates precoated with MS5 stromal cells. Cells were expanded in LTC medium supplemented with $20 \mathrm{ng} / \mathrm{ml} \mathrm{IL-3,}$ G-CSF, and TPO. Dasatinib was added as indicated concentrations. Cultures were demi-depopulated weekly for analysis. The responses to dasatinib at $0.5 \mathrm{nM}(n=15)($ a) and $5 \mathrm{nM}(n=14)$ (b) of all AMLs capable of long-term proliferation on stroma are shown, as compared to the growth of control group (\% growth of control). The time points for cell counts indicated were at week $4 / 5$. Cell counts indicated suspension and adherent hematopoietic cells that were separated by sorting CD $45^{+}$ (human) cells. c-e Growth curves of three AMLs with growth reduction by dasatinib treatment are shown. Weekly cumulative cell counts represented cells in suspension except at time point of replating, where cell counts reflected suspension and adherent hematopoietic cells. The leukemic cells both in suspension and adherent layer were harvested from the coculture at weeks 4 and 7 to initiate the second and third cocultures on new MS5 stroma (AML no. 1) 
a) Responses to dasatinib at $0.5 \mathrm{nM}$ in AML long-term culture assay $(n=15)$

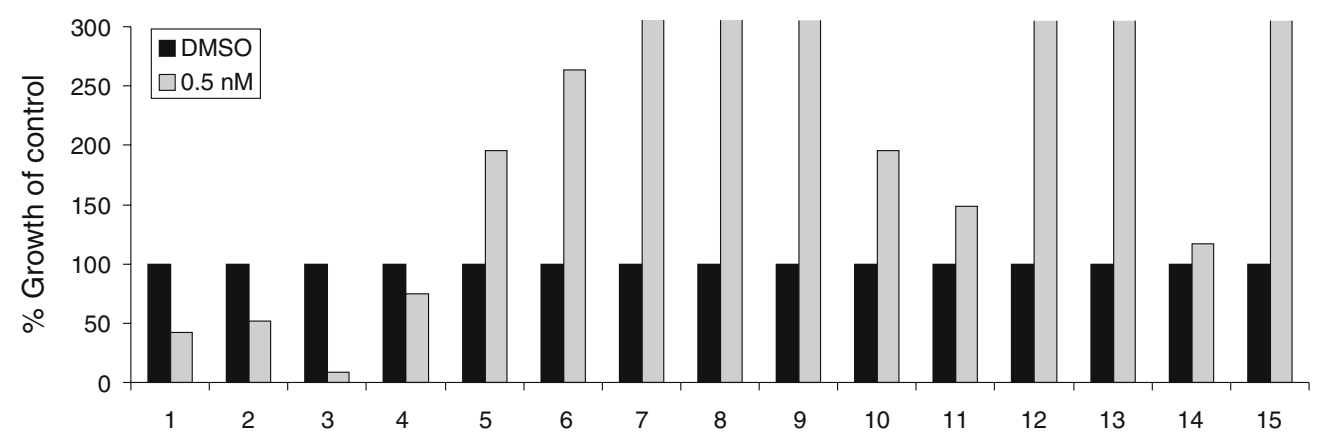

b) Responses to dasatinib at $5 \mathrm{nM}$ in AML long-term culture assay ( $\mathrm{n}=14)$

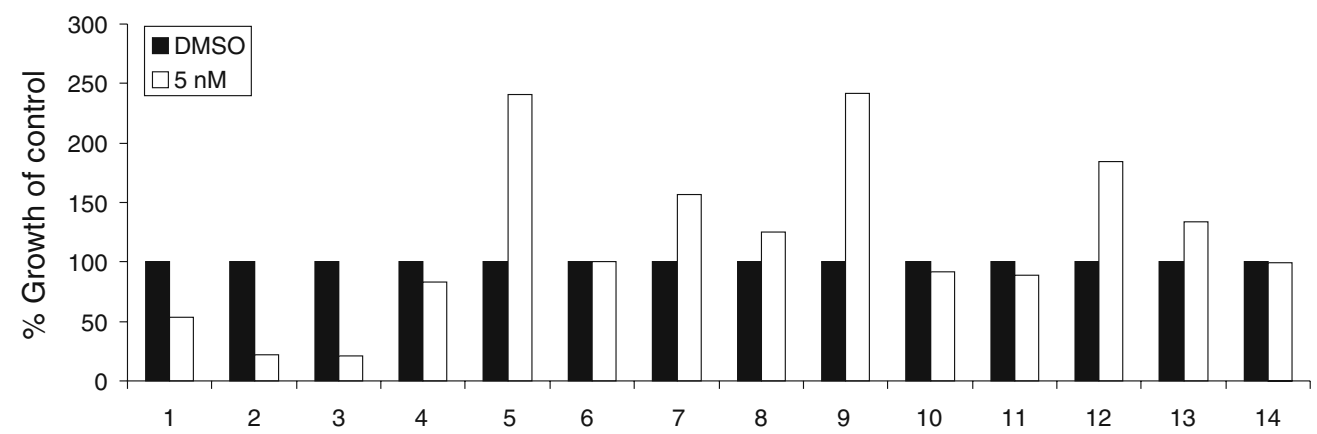

c)

AML No.1
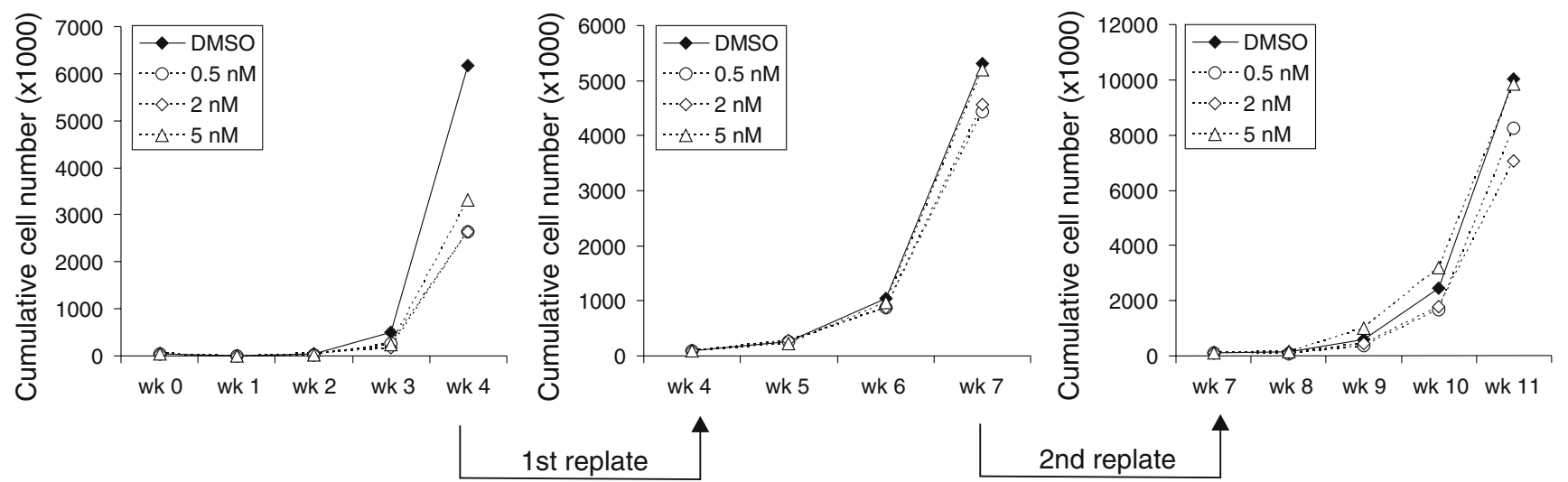

d)

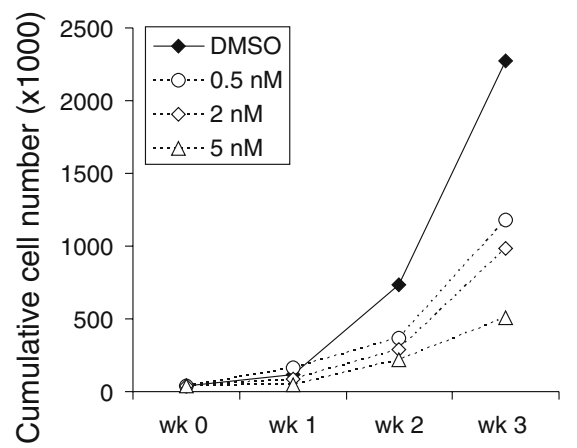

e)

AML No.3

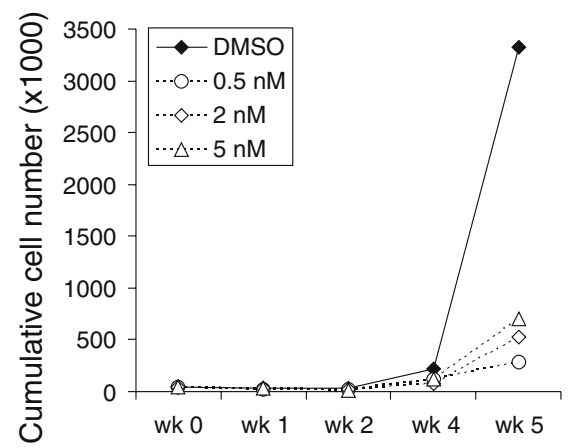


a)

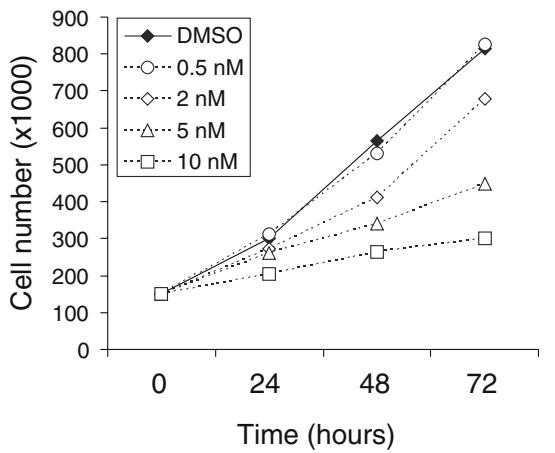

IL-3

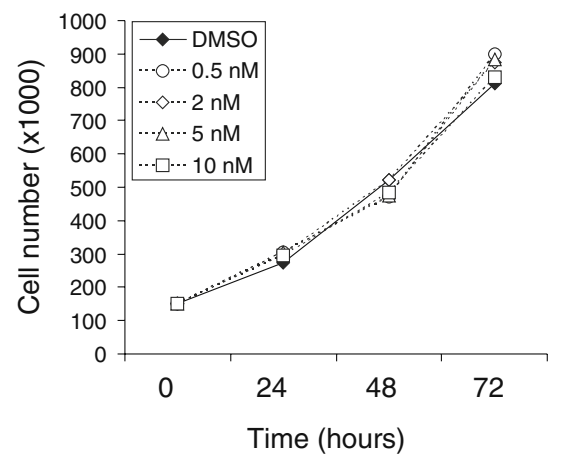

TPO

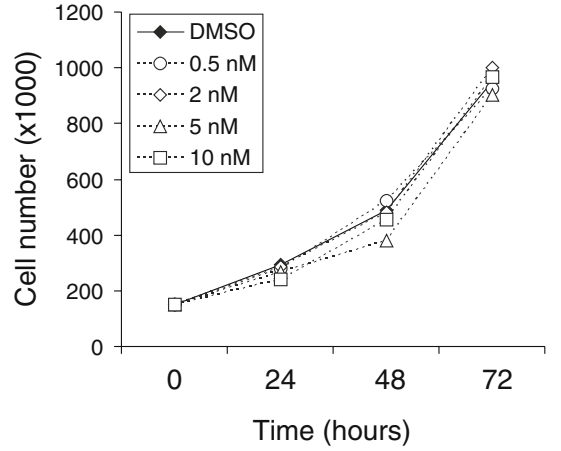

b)

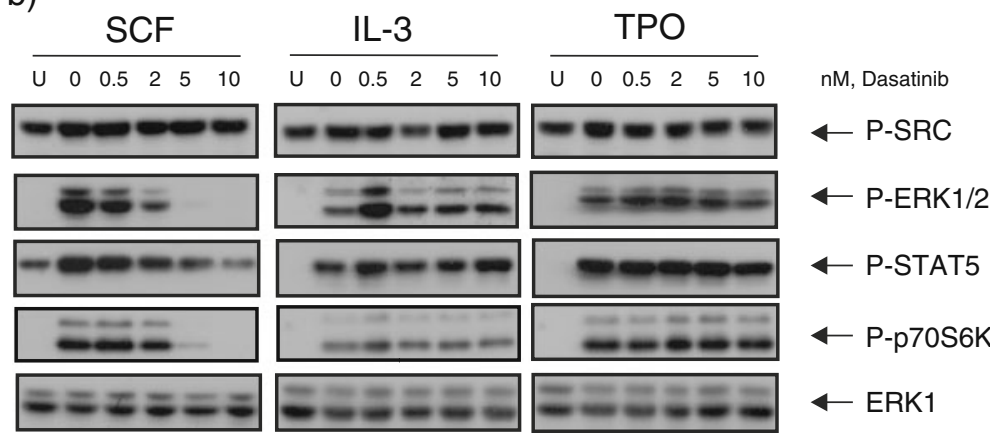

d) c)

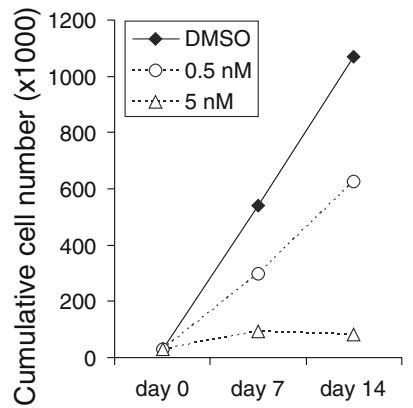

e)

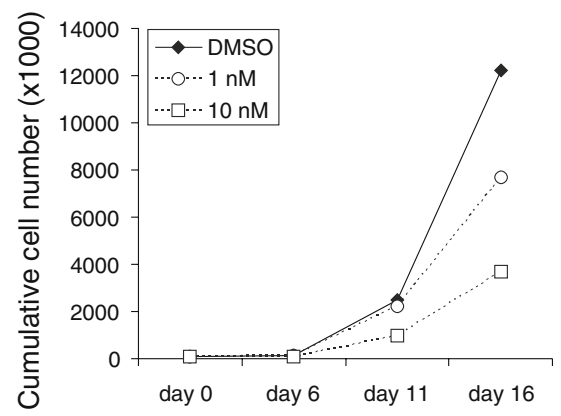

SCF+IL-3

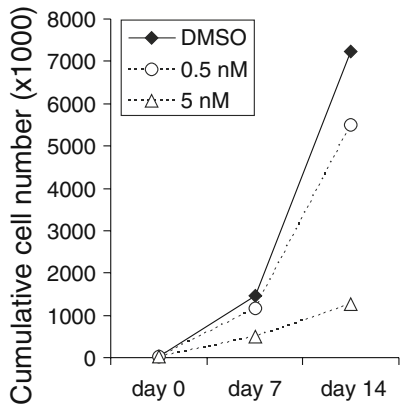

Expansion at day 14

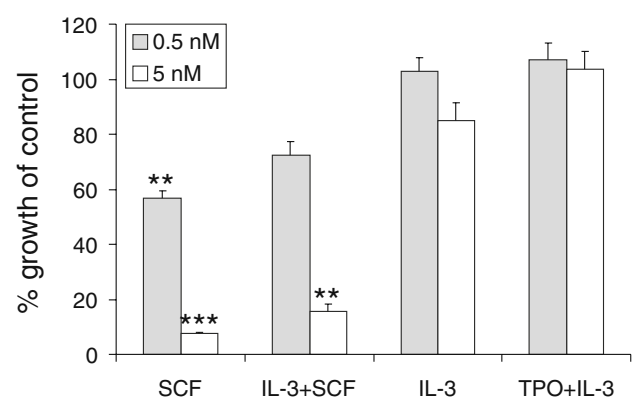

IL-3

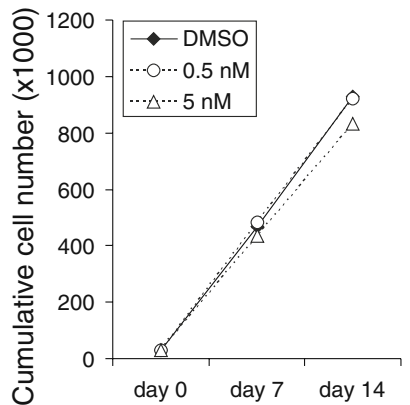

TPO+IL-3

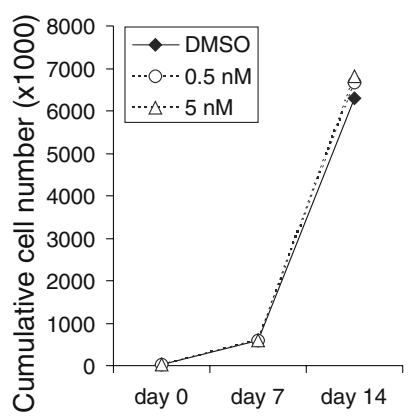

f)

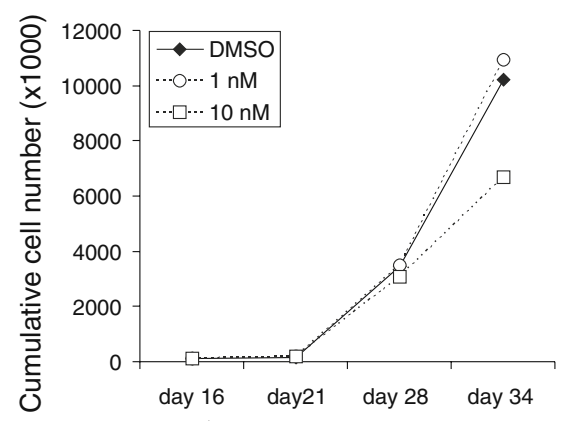

GM-CSF

$\begin{array}{lll}01 & .0 & 10\end{array} \mathrm{nM}$, Dasatinib

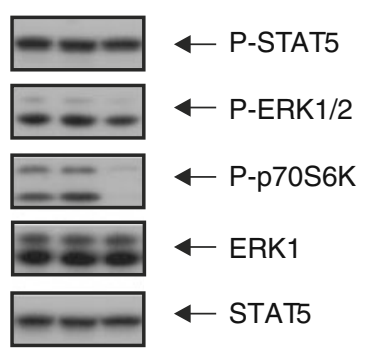

Replate on new stroma 
4 Fig. 3 Dasatinib selectively impairs SCF-induced and mutant KITdriven signal transduction and proliferation. a Mo7e cell line was cultured in RPMI with 5\% FCS, supplemented with $20 \mathrm{ng} / \mathrm{ml} \mathrm{SCF}$, IL-3, or TPO, in the absence or presence of increasing concentrations of dasatinib. Average expansion of three independent experiments is shown. b Mo7e cells were deprived of cytokine in RPMI with $0.5 \%$ FCS overnight, followed by the pretreatment with dasatinib for $2 \mathrm{~h}$. The cells were harvested for lysates after being left unstimulated (lane U) or stimulated with $20 \mathrm{ng} / \mathrm{ml} \mathrm{SCF}$, IL-3, or TPO for $15 \mathrm{~min}$. Cells $\left(3 \times 10^{5}\right)$ were loaded for Western blot, analyzing with antibodies as indicated. c Freshly isolated $\mathrm{CB} \mathrm{CD} 34^{+}$cells $\left(3 \times 10^{4}\right)$ were cultured in IMDM with $10 \% \mathrm{FCS}$, supplemented with SCF $(20 \mathrm{ng} / \mathrm{ml})$, IL-3 $(20 \mathrm{ng} / \mathrm{ml})$, or in combination (SCF+IL-3), as well as TPO $(20 \mathrm{ng} / \mathrm{ml})$ and IL-3 $(5 \mathrm{ng} / \mathrm{ml})$ (TPO+IL-3). Demi-depopulation was performed at days 7 and 14 for counting. A representative experiment out of two independent experiments is shown. d Percentages of growth after dasatinib treatment as compared to control group (\% growth of control) are shown as mean value from two independent experiments. e SKNO-1 cells $\left(10^{5}\right)$ were plated in 12-well plates precoated with MS5 stromal cells. Cells were grown in RPMI supplemented $10 \% \mathrm{FCS}$, in the presence or absence of GM-CSF (10 ng/ml). Dasatinib was added as indicated concentrations. Cultures were demi-depopulated as indicated time points for analysis. Weekly cumulative cell counts represented cells in suspension. The leukemic cells in suspension were harvested from the coculture at day 16 to initiate the second cocultures on new MS5 stroma. f SKNO-1 cells were cultured in RPMI supplemented $10 \%$ FCS, in the presence of GM-CSF $(10 \mathrm{ng} / \mathrm{ml})$, with dasatinib treatment for $4 \mathrm{~h}$. Cell lysates were prepared and subjected to Western blotting using antibodies as indicated

GM-CSF. However, in comparison to the primary culture, the cells expanded but demonstrated a reduced susceptibility to dasatinib in the second coculture $(33 \pm 2 \%$ growth inhibition at $10 \mathrm{nM}, p>0.05)$. The reduced susceptibility to dasatinib was not associated with an altered expression of GM-CSF receptor or KIT or altered phosphorylation of STAT5 or Erk (data not shown). Analysis on downstream signaling transduction pathways demonstrated that only p70S6k phosphorylation was down-regulated by dasatinib at $10 \mathrm{nM}$ in the presence of GM-CSF (Fig. 3f). Those results demonstrate dasatinib can have a strong inhibitory effect on KIT mutant cells dependent on coactivators.

\section{Discussion}

In the present study, we studied the effects of dasatinib in normal and AML leukemic CD $34^{+}$cells to demonstrate whether dasatinib might be beneficial for the treatment of AML patients. First, we demonstrated that normal CD $34^{+}$ cells were unaffected by dasatinib at a low concentration $(0.5 \mathrm{nM})$, including proliferation, differentiation, and colony formation. In the long-term culture system, $20 \%$ of the studied AML samples showed a distinct decrease in cell expansion that was already observed at low dose of dasatinib $(0.5 \mathrm{nM})$. However, dasatinib seems to affect especially the more mature leukemic progenitor population because the AML $\mathrm{CD} 34^{+}$cells responsible for replating were only partially affected by dasatinib. Comparable results have been described in CML, demonstrating that dasatinib could target especially the progenitor cell population but failed in eliminating the quiescent primitive cell fraction [33]. The AMLs that responded well to dasatinib treatment included samples with BCR-ABL and KIT mutations. BCR-ABL is rarely detected in AML. Mutations in KIT are associated with the chromosomal translocation $\mathrm{t}(8 ; 21)$ and $\operatorname{inv}(16)$ and are prognostic unfavorable parameters in this subgroup of AML [34, 35]. However, limited in vitro studies have been performed in this subgroup of patients. We have observed that AML cells with the $t(8 ; 21)$ propagate poorly in vitro in long-term culture assay, and therefore, we extended our study with myeloid leukemic cell line models including both wt and mutant KIT kinase.

We demonstrated with cell lines as well as with $\mathrm{CB}$ cells that dasatinib inhibited the SCF-mediated without inhibition on the IL-3 and TPO-mediated signaling. This finding suggests that dasatinib is a much stronger KIT kinase inhibitor than an SRC inhibitor. For the leukemic counterpart, we used the SKNO-1 cell line, which is GM-CSF dependent expressing homozygous N822K KIT mutation. Dasatinib showed significant growth reduction on longterm coculture assay, particularly in the absence of GMCSF, suggesting that dasatinib can target KIT mutation effectively. Similar to what we observed in AML CD34 cells, the inhibitory effects of dasatinib in the presence of GM-CSF were less pronounced when the cells were replated on new stroma, suggesting that also in this test, the progenitor cells were affected predominantly.

Although FLT3-ITD has been associated with increased SRC kinase activity [36], none of six AMLs with FLT3ITD demonstrated a suppressive effect on dasatinib treatment. This variability in responsiveness might be linked to our observation that SRC is poorly inhibited by dasatinib or that the activation of additional collaborative signaling pathways have a more dominant effect on the cell proliferation because of underlying mutations. However, the obtained results suggest that the in vitro assay might be of value to define potential AMLs that benefit from dasatinib treatment in vivo.

A remarkable finding was that at low-dose concentration of dasatinib $(0.5 \mathrm{nM})$, a stimulatory effect on AML CD34 ${ }^{+}$ cell proliferation was observed in a large group of AMLs. The cause of this stimulatory effect remains unclear and requires further studies. In knockout mice deficient for SRC kinases, it has been shown that these hematopoietic progenitors have an enhanced proliferative response to cytokine stimulation because of the absence of SRC kinase family members [37]. However, because at higher concentration of dasatinib this stimulatory effect almost disappeared, it is more likely that dasatinib affects the balance 
between different collaborative signaling pathways that have opposite effects on cell proliferation. Furthermore, we could exclude the possibility that the adaptor protein Lnk binding directly to Y568 in KIT is involved. Previous studies have shown that Lnk-deficient mice HSCs are hyperresponsive to growth factor stimulation in particular to TPO [38, 39]. However, in the present study, no effect of dasatinib on the TPO signaling was observed. So, the stimulatory effect in AML can unlikely be ascribed to the blocking effect of dasatinib on Lnk.

In summary, the present study demonstrates that dasatinib is an effective inhibitor of the KIT-mediated signaling in hematopoietic CD $34^{+}$stem and progenitor cells and that a subgroup of AMLs is responsive to the inhibitory effects of dasatinib in vitro, in particular, those that express BCRABL and especially KIT mutations.

Acknowledgements We would also like to acknowledge Geert Mesander and Henk Moes for help with flow cytometry, and Kirin Brewery and Amgen for providing cytokines. The authors greatly appreciate the help of Dr. J.J. Erwich, Dr. A. van Loon, and colleagues (Obstetrics Departments of University Medical Centre in Groningen, Martini Hospital Groningen) for collecting CB. We also thank Prof. Dr. M. Lübbert (Department for Hematology and Oncology, University Medical Center, Freiburg, Germany) for providing the SKNO-1 cell line.

Financial supports This work is supported by grants from the NWOVENI (2004), NWO-VIDI (2008), and KWF (RUG 2009-4275).

Open Access This article is distributed under the terms of the Creative Commons Attribution Noncommercial License which permits any noncommercial use, distribution, and reproduction in any medium, provided the original author(s) and source are credited.

\section{References}

1. Bonnet D, Dick JE (1997) Human acute myeloid leukemia is organized as a hierarchy that originates from a primitive hematopoietic cell. Nat Med 3:730-737

2. Lapidot T, Sirard C, Vormoor J, Murdoch B, Hoang T, CaceresCortes J, Minden M, Paterson B, Caligiuri MA, Dick JE (1994) A cell initiating human acute myeloid leukaemia after transplantation into SCID mice. Nature 367:645-648

3. Kelly LM, Gilliland DG (2002) Genetics of myeloid leukemias. Annu Rev Genomics Hum Genet 3:179-198

4. Lombardo LJ, Lee FY, Chen P, Norris D, Barrish JC, Behnia K, Castaneda S, Cornelius LA, Das J, Doweyko AM, Fairchild C, Hunt JT, Inigo I, Johnston K, Kamath A, Kan D, Klei H, Marathe P, Pang S, Peterson R, Pitt S, Schieven GL, Schmidt RJ, Tokarski J, Wen ML, Wityak J, Borzilleri RM (2004) Discovery of $N$-(2-chloro-6-methylphenyl)-2-(6-(4-(2-hydroxyethyl)-piperazin-1-yl)-2-methylpyrimidin-4-ylamino)thiazole-5-carboxamide (BMS-354825), a dual Src/ Abl kinase inhibitor with potent antitumor activity in preclinical assays. J Med Chem 47:6658-6661

5. Donato NJ, Wu JY, Stapley J, Gallick G, Lin H, Arlinghaus R, Talpaz M (2003) BCR-ABL independence and LYN kinase overexpression in chronic myelogenous leukemia cells selected for resistance to STI571. Blood 101:690-698

6. Gambacorti-Passerini C, Gasser M, Ahmed S, Assouline S, Scapozza L (2005) Abl inhibitor BMS354825 binding mode in Abelson kinase revealed by molecular docking studies. Leukemia 19:12671269

7. Van Etten RA (2004) Mechanisms of transformation by the BCRABL oncogene: new perspectives in the post-imatinib era. Leuk Res 28(Suppl 1):S21-S28

8. Schittenhelm MM, Shiraga S, Schroeder A, Corbin AS, Griffith D, Lee FY, Bokemeyer C, Deininger MW, Druker BJ, Heinrich MC (2006) Dasatinib (BMS-354825), a dual SRC/ABL kinase inhibitor, inhibits the kinase activity of wild-type, juxtamembrane, and activation loop mutant KIT isoforms associated with human malignancies. Cancer Res 66:473-481

9. Bromann PA, Korkaya H, Courtneidge SA (2004) The interplay between Src family kinases and receptor tyrosine kinases. Oncogene 23:7957-7968

10. Okamoto M, Hayakawa F, Miyata Y, Watamoto K, Emi N, Abe A, Kiyoi H, Towatari M, Naoe T (2007) Lyn is an important component of the signal transduction pathway specific to FLT3/ ITD and can be a therapeutic target in the treatment of AML with FLT3/ITD. Leukemia 21:403-410

11. Dos SC, Demur C, Bardet V, Prade-Houdellier N, Payrastre B, Recher C (2008) A critical role for Lyn in acute myeloid leukemia. Blood 111:2269-2279

12. Bene MC, Bernier M, Casasnovas RO, Castoldi G, Knapp W, Lanza F, Ludwig WD, Matutes E, Orfao A, Sperling C, van't Veer MB (1998) The reliability and specificity of c-kit for the diagnosis of acute myeloid leukemias and undifferentiated leukemias. The European Group for the Immunological Classification of Leukemias (EGIL). Blood 92:596-599

13. Advani AS, Rodriguez C, Jin T, Jawde RA, Saber W, Baz R, Kalaycio M, Sobecks R, Sekeres M, Tripp B, Hsi E (2008) Increased C-kit intensity is a poor prognostic factor for progression-free and overall survival in patients with newly diagnosed AML. Leuk Res 32:913-918

14. Beghini A, Peterlongo P, Ripamonti CB, Larizza L, Cairoli R, Morra E, Mecucci C (2000) C-kit mutations in core binding factor leukemias. Blood 95:726-727

15. Kolb EA, Gorlick R, Houghton PJ, Morton CL, Lock RB, Tajbakhsh M, Reynolds CP, Maris JM, Keir ST, Billups CA, Smith MA (2008) Initial testing of dasatinib by the pediatric preclinical testing program. Pediatr Blood Cancer 50:1198-1206

16. Ustun C, Corless CL, Savage N, Fiskus W, Manaloor E, Heinrich MC, Lewis G, Ramalingam P, Kepten I, Jillella A, Bhalla K (2009) Chemotherapy and dasatinib induce long-term hematologic and molecular remission in systemic mastocytosis with acute myeloid leukemia with KIT D816V. Leuk Res 33:735-741

17. van Gosliga D, Schepers H, Rizo A, van der Kolk D, Vellenga E, Schuringa JJ (2007) Establishing long-term cultures with selfrenewing acute myeloid leukemia stem/progenitor cells. Exp Hematol 35:1538-1549

18. Schuringa JJ, Schepers H (2009) Ex vivo assays to study selfrenewal and long-term expansion of genetically modified primary human acute myeloid leukemia stem cells. Methods Mol Biol 538:287-300

19. Lawley W, Hird H, Mallinder P, McKenna S, Hargadon B, Murray A, Bradding P (2005) Detection of an activating c-kit mutation by real-time PCR in patients with anaphylaxis. Mutat Res 572:1-13

20. Yokota S, Kiyoi H, Nakao M, Iwai T, Misawa S, Okuda T, Sonoda Y, Abe T, Kahsima K, Matsuo Y, Naoe T (1997) Internal tandem duplication of the FLT3 gene is preferentially seen in acute myeloid leukemia and myelodysplastic syndrome among various hematological malignancies. A study on a large series of patients and cell lines. Leukemia 11:1605-1609 
21. Schuringa JJ, Chung KY, Morrone G, Moore MA (2004) Constitutive activation of STAT5A promotes human hematopoietic stem cell self-renewal and erythroid differentiation. J Exp Med 200:623-635

22. Nam S, Williams A, Vultur A, List A, Bhalla K, Smith D, Lee FY, Jove R (2007) Dasatinib (BMS-354825) inhibits Stat5 signaling associated with apoptosis in chronic myelogenous leukemia cells. Mol Cancer Ther 6:1400-1405

23. Fiskus W, Pranpat M, Balasis M, Bali P, Estrella V, Kumaraswamy S, Rao R, Rocha K, Herger B, Lee F, Richon V, Bhalla K (2006) Cotreatment with vorinostat (suberoylanilide hydroxamic acid) enhances activity of dasatinib (BMS-354825) against imatinib mesylate-sensitive or imatinib mesylate-resistant chronic myelogenous leukemia cells. Clin Cancer Res 12:5869-5878

24. Nguyen TK, Rahmani M, Harada H, Dent P, Grant S (2007) MEK1/2 inhibitors sensitize Bcr/Abl+ human leukemia cells to the dual Abl/Src inhibitor BMS-354/825. Blood 109:40064015

25. Nunoda K, Tauchi T, Takaku T, Okabe S, Akahane D, Sashida G, Ohyashiki JH, Ohyashiki K (2007) Identification and functional signature of genes regulated by structurally different ABL kinase inhibitors. Oncogene 26:4179-4188

26. Alvarez RH, Kantarjian HM, Cortes JE (2006) The role of Src in solid and hematologic malignancies: development of newgeneration Src inhibitors. Cancer 107:1918-1929

27. Rane SG, Reddy EP (2002) JAKs, STATs and Src kinases in hematopoiesis. Oncogene 21:3334-3358

28. Doepfner KT, Boller D, Arcaro A (2007) Targeting receptor tyrosine kinase signaling in acute myeloid leukemia. Crit Rev Oncol Hematol 63:215-230

29. Thoren LA, Liuba K, Bryder D, Nygren JM, Jensen CT, Qian H, Antonchuk J, Jacobsen SE (2008) Kit regulates maintenance of quiescent hematopoietic stem cells. J Immunol 180:2045-2053

30. Kent D, Copley M, Benz C, Dykstra B, Bowie M, Eaves C (2008) Regulation of hematopoietic stem cells by the steel factor/KIT signaling pathway. Clin Cancer Res 14:1926-1930

31. Matozaki S, Nakagawa T, Kawaguchi R, Aozaki R, Tsutsumi M, Murayama T, Koizumi T, Nishimura R, Isobe T, Chihara K (1995)
Establishment of a myeloid leukaemic cell line (SKNO-1) from a patient with $\mathrm{t}(8 ; 21)$ who acquired monosomy 17 during disease progression. Br J Haematol 89:805-811

32. Becker H, Pfeifer D, Afonso JD, Nimer SD, Veelken H, Schwabe M, Lubbert M (2008) Two cell lines of $t(8 ; 21)$ acute myeloid leukemia with activating KIT exon 17 mutation: models for the 'second hit' hypothesis. Leukemia 22:1792-1794

33. Copland M, Hamilton A, Elrick LJ, Baird JW, Allan EK, Jordanides N, Barow M, Mountford JC, Holyoake TL (2006) Dasatinib (BMS-354825) targets an earlier progenitor population than imatinib in primary CML but does not eliminate the quiescent fraction. Blood 107:4532-4539

34. Beghini A, Ripamonti CB, Cairoli R, Cazzaniga G, Colapietro P, Elice F, Nadali G, Grillo G, Haas OA, Biondi A, Morra E, Larizza L (2004) KIT activating mutations: incidence in adult and pediatric acute myeloid leukemia, and identification of an internal tandem duplication. Haematologica 89:920-925

35. Paschka P, Marcucci G, Ruppert AS, Mrozek K, Chen H, Kittles RA, Vukosavljevic T, Perrotti D, Vardiman JW, Carroll AJ, Kolitz JE, Larson RA, Bloomfield CD (2006) Adverse prognostic significance of KIT mutations in adult acute myeloid leukemia with inv(16) and $t$ (8;21): a Cancer and Leukemia Group B Study. J Clin Oncol 24:3904-3911

36. Robinson LJ, Xue J, Corey SJ (2005) Src family tyrosine kinases are activated by Flt3 and are involved in the proliferative effects of leukemia-associated Flt3 mutations. Exp Hematol 33:469-479

37. Orschell CM, Borneo J, Munugalavadla V, Ma P, Sims E, Ramdas B, Yoder MC, Kapur R (2008) Deficiency of Src family kinases compromises the repopulating ability of hematopoietic stem cells. Exp Hematol 36:655-666

38. Gueller S, Gery S, Nowak V, Liu L, Serve H, Koeffler HP (2008) Adaptor protein Lnk associates with $\operatorname{Tyr}(568)$ in c-Kit. Biochem J 415:241-245

39. Seita J, Ema H, Ooehara J, Yamazaki S, Tadokoro Y, Yamasaki A, Eto K, Takaki S, Takatsu K, Nakauchi H (2007) Lnk negatively regulates self-renewal of hematopoietic stem cells by modifying thrombopoietin-mediated signal transduction. Proc Natl Acad Sci U S A 104:2349-2354 